\title{
Publishing anarchism: Pyotr Kropotkin and British print cultures, 1876-1917
}

\begin{abstract}
This paper addresses the relationship between the famous anarchist geographer Pyotr Kropotkin and his most important British editors, John Scott Keltie and James Knowles. It analyses their unpublished correspondence, which has survived, for the most part, in the state archive of the Russian Federation. Drawing on recent literature on anarchist geographies, transnational anarchism and historical geographies of science, it examines the material construction of Kropotkin's works on mutual aid, decentralisation and 'scientific anarchism', which were originally published as articles for British periodicals. The paper argues that Kropotkin's acquaintance with liberal editors was not only a matter of necessity but a conscious strategy on his part to circulate political concepts outside activist milieus, thereby taking advantage of the public venues then available for geographers. In this way, Kropotkin succeeded in getting paid for working almost full-time as an anarchist propagandist. The paper also contributes to the wider field of critical, radical and anarchist geographies by providing early examples of knowledge struggles against Creationism, Malthusianism and environmental determinisms which have lessons for the present.
\end{abstract}

Keywords: Kropotkin; public geographies; periodical press; anarchist geographies; print cultures

Federico Ferretti, "Publishing anarchist geographies: Pyotr Kropotkin and British print cultures (1877-1917)", Journal of Historical Geography vol. 57, 2017 p. 17-27 doi 10.1016/j.jhg.2017.04.006 
This paper explores the British publishing networks of the well-known anarchist geographer Pyotr Kropotkin (1842-1921), a Russian exile who spent a great part of his life and career in London. It uses primary sources to analyse Kropotkin's work for the British periodical press, in particular the Encyclopaedia Britannica (first published in Edinburgh from 1768), Statesman's Year Book (published in London from 1864), The Nineteenth Century (London, 1877) and Nature (London, 1869). Indeed, although Kropotkin's papers for The Nineteenth Century constituted the bases for some of his most famous books, such as Fields, Factories and Workshops (1898), Mutual Aid (1902), Modern Science and Anarchism (1903), The Great French Revolution (1909) and Ethics (1921), little attention has been paid to the material circumstances of these works' initial production. In order to do so, I analyse Kropotkin's unpublished correspondence with his main editors: James Thomas Knowles (1831-1908) and John Scott Keltie (1840-1927).

In recent years historical geographies of science have drawn increasingly on contextual readings, acknowledging the importance of places and material conditions for the production of knowledge through its localisations, circulations and materialistic hermeneutics. ${ }^{1}$ In this work scientific and political ideas are understood not as 'conjured out of thin air', but circulating through the world in ways which are conditioned by local situations. Understanding those contexts allows us to better understand how these ideas are different in different places. ${ }^{2}$ In this paper I discuss the significance of such local, material conditions of life and work for Kropotkin's scientific and militant activities during his time in Western Europe (and mainly in Britain) from 1876 to 1917. My main argument is that collaboration with the British periodical press presented a set of opportunities to the Russian anarchist: it was simultaneously a way to secure an income, a means to participate in key political and geographical debates (such as those on evolutionism) and a method of spreading anarchist ideas to a wider audience. The collaboration with liberals such as Knowles and Keltie should be

\footnotetext{
${ }^{1}$ D.N. Livingstone, Putting Science in its Place: Geographies of Scientific Knowledge, Chicago, 2003; D.N. Livingstone and C.W.J. Withers (Eds), Geographies of Nineteenth-Century Science, Chicago, 2011; S. Naylor, Historical geography: knowledge, in place and on the move, Progress in Human Geography 29 (2005) 626-634; J. Secord, Knowledge in transit, Isis 95 (2004) 654-672; R. Mayhew, Materialist hermeneutics, textuality and the history of geography: print spaces in British geography, Journal of Historical Geography 33 (2007) 466-488.

2 D.N. Livingstone, Dealing with Darwin: Place, Politics, and Rhetoric in Religious Engagements with Evolution, Baltimore, 2014.

Federico Ferretti, "Publishing anarchist geographies: Pyotr Kropotkin and British print cultures (1877-1917)", Journal of Historical Geography vol. 57, 2017 p. 17-27 doi 10.1016/j.jhg.2017.04.006
} 
understood as a strategy deployed by Kropotkin and other anarchist geographers to make their ideas circulate in all possible ways at a time when geographers employed varied communication strategies to gain both scientific and public status. ${ }^{3}$ Thus, I argue that there is a continuity between Kropotkin as a scientist and Kropotkin as an anarchist, challenging biographies which have described a certain disconnectedness between the 'heroic' first part of Kropotkin's life - as explorer, militant and prisoner - and the second part, starting in 1886, as an intellectual comfortably settled in an English cottage, and therefore of less interest for militant histories. ${ }^{4}$ In this sense, the paper contributes to more recent Kropotkin scholarship which tries to address the contexts for his activities more carefully. ${ }^{5}$ The materials I analyse explain how more conventional geographical publishing helped him to succeed in being paid to work as a full-time anarchist propagandist, while Kropotkin's engagement with the Russian revolutions of 1905 and 1917 shows that he never renounced direct political commitment.

Recent literature on anarchist geographies and their genealogies has shown that geography and anarchism share a number of methodological concerns in building critical views on spaces and societies. ${ }^{6}$ In this paper, I identify Kropotkin's works as 'anarchist geographies' at a time when this concept did not exist. I do so for two main reasons. First, although Kropotkin's books were not identified as geography at the time, they address topics that interest critical and radical geographers today. ${ }^{7}$ Second, the works of his that were labelled as (physical) geography, such as Kropotkin's papers for the Geographical Journal, which hardly mention anarchism explicitly at all, and have generally been deemed more 'conventional' by his biographers, did have political relevance for

\footnotetext{
${ }^{3}$ C.W.J. Withers, Towards a history of geography in the public sphere, History of Science (1998) 45-78; C.W.J. Withers, D. Finnegan and R. Higgitt, Geography's other histories? Geography and science in the British Association for the Advancement of Science, 1831-1933, Transactions of the Institute of British Geographers 31 (2006) 433-451. ${ }^{4}$ I. Avakumovič and G. Woodcock, The Anarchist Prince: A Biographical Study of Peter Kropotkin, New York, 1971; C. Cahm, Kropotkin and the Rise of Revolutionary Anarchism: 1872-1886, Cambridge, 1989; M. Miller, Kropotkin, Chicago, 1976.

${ }^{5}$ M. Adams, Kropotkin, Read and the Intellectual History of British Anarchism, London, 2015; R. Kinna, Kropotkin: Reviewing the Classical Anarchist Tradition, Edinburgh, 2016.

${ }^{6}$ S. Springer, A.J. Barker, G. Brown, A. Ince and J. Pickerill, Reanimating anarchist geographies: a new burst of colour, Antipode 44 (2012) 1591-1604; F. Ferretti, Élisée Reclus, pour une Géographie Nouvelle, Paris, 2014; S. Springer, The Anarchist Roots of Geography: Toward Spatial Emancipation, Minneapolis, 2016.

${ }^{7}$ Considering Kropotkin's rediscovery in the 1970s, I would argue that these works had an influence on the development of contemporary geographies. See M.M. Breitbart, Impressions of an anarchist landscape, Antipode 7 (1975) 44-49; R. Peet, For Kropotkin, Antipode 7 (1975) 42-43.
}

Federico Ferretti, "Publishing anarchist geographies: Pyotr Kropotkin and British print cultures (1877-1917)", Journal of Historical Geography vol. 57, 2017 p. 17-27 doi 10.1016/j.jhg.2017.04.006 
nineteenth-century debates on science and politics because Kropotkin, like other anarchist geographers, used them as a way of 'attacking religion'. 8

In producing these works, Kropotkin's relationship with his editors was a compromise on his part motivated by both political and economic opportunities. This was a period in the history of the book characterised by an increasing commodification of knowledge with authors struggling to maintain editorial control of their texts. ${ }^{9}$ As I will show, from the 1870 s Keltie wittingly acted as a sort of 'Trojan horse' for Kropotkin, the exposure of whose works to British publics was facilitated by his editor's personal acquaintance with the Russian geographer and their shared social networks. From the 1880s onwards, Knowles then became the principal orchestrator of Kropotkin's popularity among British publics, showing himself to be even cleverer than Keltie in sensing editorial opportunities.

To examine these relationships I draw on sources surviving in the State Archive of the Russian Federation (GARF) in Moscow, where unpublished letters received by Kropotkin from more than three thousand international correspondents have been the object of exploratory studies. ${ }^{10}$ I focus here on the folders containing more than a hundred letters from Knowles from 1882 to 1906 and almost four hundred from Keltie from 1877 to 1917. Kropotkin's answers survive only partially in Keltie's archives at the Royal Geographical Society (RGS) in London (less than hundred letters from 1882 to 1917) and in Knowles's archives in Westminster Library (only few letters from 1905 to 1906), making it sometimes difficult to reconstruct their exchanges in detail.

The first part of the paper explains the importance of the periodical press for disseminating the ideas of early anarchist geographers throughout the English-speaking world, drawing upon recent literature on both anarchist geographies and geographies of print culture. In the second section, I begin by examining the correspondence between Kropotkin and Keltie using the concept of

\footnotetext{
${ }^{8}$ M. Nettlau, Eliseo Reclus: Vida de un Sabio Justo y Rebelde, volumen 2, Barcelona, 1930, 49.

${ }^{9}$ I. Keighren, C.W.J. Withers and B. Bell, Travels into Print: Exploration, Writing, and Publishing with John Murray, 1773-1859, Chicago, 2015.

${ }^{10}$ F. Ferretti, The correspondence between Élisée Reclus and Pëtr Kropotkin as a source for the history of geography, Journal of Historical Geography 37 (2011) 216-222; D. Slatter, The correspondence of P.A. Kropotkin as historical source material, Slavonic and East European Review 72 (1994) 277-288.

Federico Ferretti, "Publishing anarchist geographies: Pyotr Kropotkin and British print cultures (1877-1917)”, Journal of Historical Geography vol. 57, 2017 p. 17-27 doi 10.1016/j.jhg.2017.04.006
} 
sociability to highlight the importance of friendship and shared personal networks for launching Kropotkin's reputation in the British publishing world. I then analyse the contours of the publishing arrangements negotiated between Keltie and Kropotkin, and expose the ways in which these masked their political differences. The depth of these differences were only revealed when Kropotkin left England in 1917 and returned to Russia. The final part of the paper addresses the relationship between Kropotkin and Knowles, and shows how, while initially productive, it deteriorated to a point, with the first Russian revolution in 1905, when relations were broken off. However, before these impasses were reached Kropotkin had produced a remarkable array of 'anarchist geographies' through the liberal British periodical press.

\section{MILITANT NETWORKS AND PUBLISHING NETWORKS}

In recent years, a rich interdisciplinary literature has addressed anarchism, past and present, as a transnational movement whose multilingual and multicultural characteristics were due mainly to many of its militants being politically persecuted exiles or economic migrants. ${ }^{11}$ The group of anarchist geographers established in Switzerland during the exile of French militants and scholars such as Élisée Reclus (1830-1905), and other political refugees, such as Mikhail Dragomanov (1841-1895), Lev Mečnikov/Léon Metchnikoff (1838-1888) and Kropotkin himself, has been

studied as an example of these transnational militant and intellectual networks. ${ }^{12}$ London, where Kropotkin resided for decades, and where Reclus also often travelled, is considered as one of the main international hubs for transnational anarchism in the Age of Empire. ${ }^{13}$

In a recent book on Kropotkin's influence on the British anarchist intellectual Herbert Read (18931968), Matthew Adams argues that 'while Kropotkin's political thoughts germinated in response to Russian autocracy, grew in the Swiss hills, and flowered after contact with the tradition of French socialism, his British context was central to the mature elaboration of this politics. Freshly rooted

\footnotetext{
${ }^{11}$ C. Bantman, The French Anarchists in London, 1880-1914: Exile and Transnationalism in the First Globalisation, Liverpool, 2013; S. Hirsch and L. Van der Walt (Eds), Anarchism and Syndicalism in the Colonial and Postcolonial World, 1870-1940, Leiden and Boston, 2010; D. Turcato, Italian anarchism as a transnational movement, 1885-1915, International Review of Social History 52 (2007) 407-444.

${ }^{12}$ Ferretti, Élisée Reclus; P. Pelletier, Géographie et Anarchie: Reclus, Kropotkine, Metchnikoff, Paris, 2013.

${ }^{13}$ Bantman, The French Anarchists; P. Di Paola, The Knights Errant of Anarchy: London and the Italian Anarchist Diaspora (1880-1917), Liverpool, 2013.
}

Federico Ferretti, "Publishing anarchist geographies: Pyotr Kropotkin and British print cultures (1877-1917)”, Journal of Historical Geography vol. 57, 2017 p. 17-27 doi 10.1016/j.jhg.2017.04.006 
in British soil, Kropotkin turned his attention to translating the concepts of continental anarchism for a new audience'. Thus, if anarchism is transnational, its outcomes are situated and exposed to local influences. As Adams notes, Kropotkin's commitment to 'sell anarchism to the British' implied his insertion into that local political and intellectual context, something also shown by other studies. ${ }^{14}$ Kropotkin was also inserted into international debates over Darwinism, and his ideas on mutual aid and cooperation as factors of evolution were a key part of anarchist thought. ${ }^{15}$

If Adams mainly addresses the political contexts of Kropotkin's commitment to 'British science', I am interested in delving deeper into contexts not customarily understood as politically radical, such as the publications edited by Keltie and Knowles, to understand what I consider to be Kropotkin's strategy for 'sell[ing] anarchism'. A willingness to circulate anarchist ideas within all social milieus, including not only militant and popular audiences but also the bourgeois public of scientific journals and learned societies, also characterised Élisée Reclus and implied the development of a range of forms of propaganda - journals, books, brochures and conferences - at a time when both popular books and the periodical press were taking advantage of rapidly increasing literacy. ${ }^{16}$ Indeed, research on the correspondence between Reclus and his French publishers, Hachette and Hetzel, has shown that the anarchist geographer exploited the commercial success of his writings to pay a full editorial team composed of scholars who were at the same time militants and worked together on concepts such as federalism, mutual aid and critiques of Malthusianism, spreading them through both specialist and popular print. ${ }^{17}$ Kropotkin was a part of this network and worked for Reclus's New Universal Geography in 1880-1881 and during his imprisonment in France from December 1882 to January $1886 .{ }^{18}$ His correspondence with Keltie and Knowles can be compared to the contemporary and parallel negotiations that Reclus conducted

\footnotetext{
${ }^{14}$ Adams, Kropotkin, 26-27, 29; G. Kearns, The political pivot of geography, The Geographical Journal 170 (2004) 337-346; J. MacLaughlin, Kropotkin and the Anarchist Intellectual Tradition, London, 2016.

${ }^{15}$ G. Kearns, Geopolitics and Empire: The Legacy of Halford Mackinder, Oxford, 2009; D.N. Livingstone, Science, text and space: thoughts on the geography of reading, Transactions of the Institute of British Geographers 30 (2005) 391-401; A. Girón Sierra, Kropotkin between Lamarck and Darwin: the impossible synthesis, Asclepio 55 (2003) 189213; S.J. Gould, Kropotkin was no crackpot, Natural History 106 (1997) 12-21.

${ }^{16}$ G. Dawson, R. Noakes and J.R. Topham, Introduction, in: G. Cantor, G. Dawson, G. Godday, R. Noakes, S. Shuttleworth and J.R. Topham, Science in the Nineteenth-Century Periodical: Reading the Magazine of Nature, Cambridge, 2004, 1-36.

${ }^{17}$ F. Ferretti, Élisée Reclus, Lettres de Prison et d'Exile, Lardy, 2012.

${ }^{18}$ Ferretti, The correspondence between Élisée Reclus and Pëtr Kropotkin.

Federico Ferretti, "Publishing anarchist geographies: Pyotr Kropotkin and British print cultures (1877-1917)", Journal of Historical Geography vol. 57, 2017 p. 17-27 doi 10.1016/j.jhg.2017.04.006
} 
with his Paris publishers during his imprisonment after the 1871 Paris Commune and his subsequent exile in Switzerland from 1872 to 1890 . Kropotkin and Reclus were both famous scholars who experienced difficult material conditions due to their radical political commitments. They were both imprisoned, exiled and had difficulty finding university appointments. Yet their commercial success as authors allowed them to earn their livelihood while publishing politically relevant material because they considered science in itself to be political even when it was not explicitly labelled as 'anarchist' politics. ${ }^{19}$

Thus, in Modern Science and Anarchism Kropotkin defined anarchism as closely associated with science, which he understood as the rational application of experimental methods to natural and social matters, refusing any recourse to metaphysics and challenging religion through the enhancement of secular knowledge and empirical research. ${ }^{20}$ This paralleled an ongoing debate in the British world on the conflicting relations between religion and science. The famous 1874 'Belfast address' by John Tyndall (1820-1893) before the British Association for the Advancement of Science was followed by harsh polemics in which Tyndall was judged to 'believe in nature without a God' and to be promoting atheist and materialistic ideas. ${ }^{21}$ According to David Livingstone, however, Tyndall's aim was not to enhance atheism and materialism, but to 'throw down the gauntlet to the religious establishment by insisting that theology had no business meddling in scientific matters'. He did so, Livingstone argues, in the context of a 'concerted campaign on the part of a number of professionalising scientists to wrest cultural authority from the hands of the clergy'. Nevertheless, Tyndall was well aware that his speech 'was intellectual iconoclasm in Calvinist Belfast [and] political dynamite in Catholic Ireland too'. ${ }^{22}$ This explains why Tyndall, along with other evolutionist naturalists, was one of the Anglophone intellectual references that Kropotkin quoted as promoting secular education against 'superstition', taking

\footnotetext{
${ }^{19}$ Ferretti, Élisée Reclus.

${ }^{20}$ P. Kropotkin, Modern Science and Anarchism, Philadelphia, 1903.

${ }^{21}$ B. Lightman, Scientists and materialists in the periodical press: Tyndall's Belfast address, in: G. Cantor and S. Shuttleworth (Eds), Science Serialized: Representations of the Sciences in Nineteenth-Century Periodicals, Cambridge MA, 2004, 209.

${ }^{22}$ D.N. Livingstone, Debating Darwin at the Cape, Journal of Historical Geography 52 (2016) 9.

Federico Ferretti, "Publishing anarchist geographies: Pyotr Kropotkin and British print cultures (1877-1917)”, Journal of Historical Geography vol. 57, 2017 p. 17-27 doi 10.1016/j.jhg.2017.04.006
} 
seriously the value of rational science to challenge not only the religious establishment but the idea of religion itself. ${ }^{23}$ In such ways, science served Kropotkin's anarchist political agenda.

The periodical press offered a number of opportunities for Kropotkin because it was the prime vehicle through which scientists diffused their ideas. The first British periodical to which he contributed, Nature, had published the full text of Tyndall's address. According to Kropotkin, this was part of a movement of "prominent men who dared to bring up the results of the most complicated scientific research in a shape accessible to the general reader' ${ }^{24}$ Other studies have shown that such journals were 'so distinctive of science that they seem to be a necessary part of it', observing that they became one of the privileged battlefields for the controversy between science and religion. ${ }^{25}$ Another opportunity for Kropotkin was represented by the interest open-minded individuals like Keltie and Knowles showed in his work. According to Helen Small, Knowles publicly committed to supporting the publication of evolutionary scientific work in The Nineteenth Century, opening the door to Kropotkin too. ${ }^{26}$

More broadly, the editorial networks and publishing strategies that anarchist geographers like Kropotkin and Reclus developed are an example of the importance of print cultures for understanding the construction of geographical knowledge both in the periodical press and through the 'geographies of the book'. ${ }^{27}$ The effectiveness of unpublished correspondence in reconstructing geographical publishing networks has been shown for Reclus and for nineteenth-century travel writing. ${ }^{28}$ The study of the correspondence between Kropotkin and his British publishers is, therefore, a first contribution to the better understanding of his approach to British reading publics. Whilst Gerry Kearns has emphasized the 'academic and political tolerance' of members of the Royal Geographical Society in welcoming political refugees such as Kropotkin, I focus here, rather,

${ }^{23}$ P. Kropotkin, What geography ought to be, The Nineteenth Century 18 (1885) 941.

${ }^{24}$ J. Tyndall, Inaugural address, Nature (10 August 1874) 309-319; Kropotkin, What geography ought to be, 940.

${ }^{25}$ J.R. Topham, Anthologizing the book of nature: the origins of scientific journal and circulation of knowledge in late Georgian Britain, in: B. Lightman, G. McOuat and L. Stewart, The Circulation of Knowledge between Britain, India and China, Leiden and Boston, 2013, 120.

${ }^{26} \mathrm{H}$. Small, Science, liberalism and the ethics of belief, the Contemporary Review in 1877, in: Cantor and Shuttleworth (Eds), Science Serialized, 252.

${ }^{27}$ I. Keighren, Bringing Geography to Book: Ellen Semple and the Reception of Geographical Knowledge, London, 2010; M. Ogborn and C.W.J. Withers (Eds), Geographies of the Book, Farnham, 2010.

${ }^{28}$ Ferretti, Élisée Reclus.

Federico Ferretti, "Publishing anarchist geographies: Pyotr Kropotkin and British print cultures (1877-1917)", Journal of Historical Geography vol. 57, 2017 p. 17-27 doi 10.1016/j.jhg.2017.04.006 
on the anarchists' initiatives to enhance their relations with 'mainstream' geographers and scientists. Critically, I analyse the conscious strategies they deployed to enter what Pierre Bourdieu called the 'scientific field'. ${ }^{29}$ As the next section shows, it was the personal friendship between Kropotkin and Keltie that is at the beginning of the story I want to tell.

\section{'ENOUGH TO MAKE ONE A LEVELLER': KROPOTKIN AND KELTIE}

\section{Geography, politics and sociability networks}

Recent studies by Pietro di Paola on the anarchist international milieus in London have drawn upon the concept of sociability, as defined by French historian Maurice Agulhon. This underscores the importance of informal networks and personal friendship in the circulation of ideas and the fabric of political and cultural life. ${ }^{30}$ They help sustain feelings of solidarity especially amongst exiles, even where there are manifest political differences. In this section, I demonstrate how the profound friendship, scientific and, at least partial, political sympathy between Kropotkin and Keltie was the basis for their forty-year collaboration, with the result that Keltie acted as a sort of 'Trojan horse' for the spread of Kropotkin's ideas in Britain. Nevertheless, as I explain below, this deep-rooted collaboration ended when the Russian revolution exposed the depth of their political differences.

Kropotkin, a Russian prince and an explorer of Siberia, Finland and Central Asia, fled to Britain in 1876 from the Peter and Paul fortress in St. Petersburg where he was detained as a political dissident. ${ }^{31}$ Keltie, a Scotsman who had been trained in Presbyterian theology but refused to enter the ministry, had moved from Edinburgh to London in 1871 to join the editorial staff of Macmillan. ${ }^{32}$ In the following decades he worked for a number of editorial endeavours in which he systematically involved Kropotkin, such as the Statesman's Year Book, The Geographical Journal

\footnotetext{
${ }^{29}$ Kearns, The political pivot of geography, 345; P. Bourdieu, The specificity of the scientific field and the social conditions of the progress of reason, Social Science Information 14 (1975) 19-47.

${ }^{30} \mathrm{M}$. Agulhon, La sociabilité méridionale, Confréries et associations dans la vie collective en Provence orientale la fin du XVIIIe siècle, Aix-en-Provence, 1966; P. Di Paola, Club anarchici di Londra: sociabilità, politica, cultura, Società e Storia 108 (2005) 353-375.

${ }^{31}$ Avakumovič and Woodcock, The Anarchist Prince; M. Bassin, Imperial Visions: Nationalist Imagination and Geographical Expansion in the Russian Far East, 1840-1865, Cambridge, 1999.

${ }^{32}$ M.J. Wise, The Keltie Report 1885 and the teaching of geography in Great Britain, The Geographical Journal 152 (1986) 367-382.
}

Federico Ferretti, "Publishing anarchist geographies: Pyotr Kropotkin and British print cultures (1877-1917)", Journal of Historical Geography vol. 57, 2017 p. 17-27 doi 10.1016/j.jhg.2017.04.006 
and the tenth edition of the Encyclopaedia Britannica. Kropotkin described in his autobiographical memoir how that came about:

'I went, very naturally, to the office of Nature. ... The editor wanted to increase the column of "Notes" and found that I wrote them exactly as they were required. A table was consequently assigned to me in the office and scientific reviews in all possible languages were piled upon it. "Come every Monday, Mr. Levashoff", I was told .... I soon managed very nicely, with my Nature notes and my Times paragraphs, to get a living. ... One day, however, Mr. Keltie took from the shelves several Russian books, asking me to review them for Nature. I looked at the books, and, to my embarrassment, saw that they were my own works on the Glacial Period and the Orography of Asia. ... I decided to take them back the next day and explain to Mr. Keltie that, although I had introduced myself under the name of Levashoff, I was the author of these books and could not review them. Mr. Keltie knew from the papers about Kropotkin's escape and was very much pleased to discover the refugee safe in England. ... From that day a friendship, which still continues, grew up between us' ${ }^{33}$

The earliest of Keltie's letters to Kropotkin in the Moscow archive is dated 1877 and is addressed to 'My dear Levashoff'. This, however, seems to be a joke between the two men because by 1877 Keltie certainly knew who Kropotkin was. At that time the Russian prince had heard the sirens of revolution in the Jura mountains where the first anarchist organisation in history, the Fédération Jurassienne, became the centre of his activities while he also worked on a project for Keltie. One of the Fédération founders, Kropotkin's friend James Guillaume (1844-1916), later recounted that Kropotkin obtained from Keltie 'a rather big project, one he could do anywhere, for an English geographical dictionary [Gazetteer] then in preparation, for which he was appointed to Russia and Siberia'. ${ }^{34}$ Keltie's letters show that Kropotkin, skilled in a number of northern and eastern European languages, assisted him with particular entries for Sweden, Norway, Germany and Poland, and that Guillaume was also involved in the chapter on Italy. ${ }^{35}$ In sum, a remarkable set of

\footnotetext{
${ }^{33}$ P. Kropotkin, Memoirs of a Revolutionist, volume 2, London, 1899, 186-187.

${ }^{34}$ J. Guillaume, L'Internationale, Documents et Souvenirs, volume 4, Paris, 1910, 146.

${ }^{35}$ Gosudarstvennyi Arkhiv Rossiiskoi Federatsii, Fondy P-1129, op. 2 khr 1308 [hereafter GARF, 1129, 2, 1308], Keltie to Kropotkin, 5 March 1878; Keltie to Kropotkin, 15 September 1881.

Federico Ferretti, "Publishing anarchist geographies: Pyotr Kropotkin and British print cultures (1877-1917)”, Journal of Historical Geography vol. 57, 2017 p. 17-27 doi 10.1016/j.jhg.2017.04.006
} 
anarchism's 'Founding Fathers' worked for Keltie's Gazetteer, offering the editor multilingual skills and specialist knowledge. For the anarchists, what was first an economic necessity soon became a way to circulate their ideas in wider contexts.

In these first surviving letters, there are also examples of Keltie engaging his correspondent in political discussion. Keltie shows himself to be supportive of Russian dissident movements and shared his correspondent's hatred for autocracy, praising the courage of Vera Zasulich (18491919), a Russian woman who tried to kill Fyodor Trevor, the governor of St. Petersburg famous for his bloody repression of the Polish uprisings. 'Do you know the brave lady who shot the oppressor in St. Petersburg?' ${ }^{36}$ he asked Kropotkin. The answer does not survive, but we know that Zasulich fled to Switzerland, where Keltie's later comment that 'I am pleased to hear that the heroic Vera Zasulich is safe and secure' suggests she was acquainted with Kropotkin. ${ }^{37}$ Furthermore, from the beginning, Keltie was intrigued by Kropotkin's acquaintance with Reclus and asked after him. ${ }^{38}$ Indeed, Keltie tried to use Kropotkin to secure Reclus's services for his Gazetteer, asking 'if your friend Reclus would tell me what authorities to get to enable me to complete France', Spain and Portugal. $^{39}$ Keltie also expressed interest in Reclus's anarchist thinking, reading 'with great interest' his L'évolution, la révolution et l'idéal anarchique, which Kropotkin had sent him along with Le Révolté, a journal published from 1879 to 1887 that was one of the main expressions of Reclus's and Kropotkin's anarchism. ${ }^{40}$ As Keltie answered: ‘[This journal] interests me greatly ... Respect and regard to M. Élisée Reclus. Your old friend Keane is assisting to translate his Magnum Opus'. ${ }^{41}$

Keltie and Kropotkin's friendship is also demonstrated by the discussion in their letters of private matters and family life. ${ }^{42}$ Yet such personal issues might also reveal the differences between the two men. Keltie became curious in 1882 when he read indignant commentaries in the newspapers

\footnotetext{
${ }^{36}$ GARF, 1129, 2, 1308, Keltie to Kropotkin, 18 February 1878.

${ }^{37}$ GARF, 1129, 2, 1308, Keltie to Kropotkin, 14 August 1878.

${ }^{38}$ GARF, 1129, 2, 1308, Keltie to Kropotkin, 14 August 1878.

${ }^{39}$ GARF, 1129, 2, 1308, Keltie to Kropotkin, 15 August 1878; Keltie to Kropotkin, 11 December 1878.

${ }^{40}$ GARF, 1129, 2, 1308, Keltie to Kropotkin, February 1880; Kinna, Kropotkin.

${ }^{41}$ GARF, 1129, 2, 1308, Keltie to Kropotkin, 9 April 1880. Augustus Henry Keane (1833-1912) was the co-editor of the English version of Reclus's New Universal Geography.

${ }^{42}$ GARF, 1129, 2, 1308, Keltie to Kropotkin, 24 April 1878.
}

Federico Ferretti, "Publishing anarchist geographies: Pyotr Kropotkin and British print cultures (1877-1917)”, Journal of Historical Geography vol. 57, 2017 p. 17-27 doi 10.1016/j.jhg.2017.04.006 
that the 'free union' of Reclus's daughters, Magali and Jeannie, with two young men, had been celebrated with a public ceremony. The Scotsman wrote to Kropotkin declaring himself astonished that Reclus had 'given away his two daughters to live with two men without obtaining any guarantees from the latter' ${ }^{43}$ Kropotkin's answer focused first on disputing the idea of 'giving' someone away and insisted on the girls' free choice rather than the sanction of the union by church or state. '[Reclus's] daughters are very intellectual girls who understand that the sanction of a curé or of a maire is not a guarantee for the happiness of marriage. I think that the marriage is too holy a thing to be profaned by the admission of such [illegible] of the marriage's holiness as the curés and the maires are. If not absolutely necessary for some practical reason, it never ought to be done. Marriage is a personal thing in which neither the Church or the State have nothing to see'. ${ }^{44}$ This looks like an attempt to convince Keltie of the anarchist position, demonstrating the depth and frankness of the intellectual exchange between the two men as well as Kropotkin's willingness to set out his political positions in what was otherwise a business correspondence.

An 1878 proposal by Keltie to Kropotkin gives a clear example of the complicity between the two men. As the Scotsman wrote, 'The Times is about to give regularly the latest scientific news. I have been asked to help them. So if you can send me any fresh, important paragraphs ... I shall send them in with your name - Levashoff' ${ }^{45}$ Thus, Keltie was willing to help Kropotkin hide his identity while he did not have formal status in Britain. In turn, Kropotkin, like other anarchist authors was willing to forego any editorial credit, being primarily interested in the circulation of his ideas. At times this might mean Kropotkin's work appearing as Keltie's. For instance, Keltie wrote that 'The Times has taken your note on Archaeology in Russia. I put my name ... and will get the money for you and send it'. ${ }^{46}$ However, Keltie's letters also confirm that Kropotkin was then more interested in pursuing revolutionary activity in Switzerland than writing for him. The British editor often jokingly complained about his correspondent's silences, asking 'What are you about? Where are

${ }^{43}$ GARF, 1129, 2, 1308, Keltie to Kropotkin, 30 October 1882.

${ }^{44}$ Royal Geographical Society with the Institute of British Geographers Archives [hereafter RGS-IBG],, Manuscripts CB7, Kropotkin to Keltie, 6 November 1882.

${ }^{45}$ GARF, 1129, 2, 1308, Keltie to Kropotkin, 28 August 1878.

${ }^{46}$ GARF, 1129, 2, 1308, Keltie to Kropotkin, 5 December 1878.

Federico Ferretti, "Publishing anarchist geographies: Pyotr Kropotkin and British print cultures (1877-1917)”, Journal of Historical Geography vol. 57, 2017 p. 17-27 doi 10.1016/j.jhg.2017.04.006 
you? Is it you who have been opening the sluices of the Amu Darya? Or are you in Madrid or Kabul?'47

This complicity also emerges in the letters that state Keltie's antipathy to the Russian aristocracy. The British editor recounted to Kropotkin his difficult relations with Baron Osten-Sacken (18281906), a Russian diplomat who collaborated with Nature and the Gazetteer and who started, for obscure reasons, to manifest hostility towards Keltie. Keltie expressed his disappointment, asking for Kropotkin's advice and offering some sarcastic comments about the social class from which Prince Kropotkin also came: "I suppose he thinks [my behaviour] ... "impertinent" in so humble an individual as I am, asking to justify myself before a Russian Baron. It is enough to make one a leveller' ${ }^{48}$ Here tensions within scientific publishing reflected political conflicts and a common sensibility emerged between Keltie, a relatively depoliticised liberal author, and anarchists such as Kropotkin and Reclus on the basis of a common faith in science and a common antipathy to the aristocracy.

Overall, this correspondence highlights the nature of the relationship between Kropotkin and Keltie and the underlying rationale for their collaboration. They shared common social and scientific networks that offered forms of solidarity. For example, Elie Reclus (1827-1904), Élisée's brother and Kropotkin's friend, an anti-racist and anti-colonialist ethnographer, lived in London from 1878 to 1880 and was acquainted with Keltie. ${ }^{49}$ Examining these networks through the idea of sociability helps to provide contextual understandings in the history of geography and shows the working of informal and extra-institutional networks in both science and politics. In what follows, I explain the editorial aspects of Kropotkin's and Keltie's unfolding relationship, specifically focusing on how their political differences were set aside for practical purposes, yet resurfaced at the outbreak of the 1917 Russian revolution. At that point the limitations of Kropotkin and Keltie's editorial bargain emerged because this historical event highlighted the differences between their respective political views that decades of friendly collaboration had never removed.

47 GARF, 1129, 2, 1308, Keltie to Kropotkin, 7 November 1878. Keltie is probably referring to some recent geographical correspondence on the opening of artificial canals in Central Asia.

${ }^{48}$ GARF, 1129, 2, 1308, Keltie to Kropotkin, 25 February and 4 March 1879.

${ }^{49} \mathrm{~F}$. Ferretti, The murderous civilization: anarchist geographies, ethnography and cultural differences in the works of Elie Reclus, Cultural Geographies 24 (2017) 111-129; GARF, 1129, 2, 1308, Keltie to Kropotkin, 5 April 1879. Federico Ferretti, "Publishing anarchist geographies: Pyotr Kropotkin and British print cultures (1877-1917)”, Journal of Historical Geography vol. 57, 2017 p. 17-27 doi 10.1016/j.jhg.2017.04.006 


\section{Kropotkin and Keltie: bargaining for science}

Their friendship formed the basis for the editorial collaboration between Kropotkin and Keltie in the context of Keltie's work for the RGS and for editorial enterprises such as the Encyclopaedia Britannica ${ }^{50} \mathrm{I}$ argue in what follows that their common goal to support geographical writing enabled them to foreground their mutual interests and, simultaneously, downplay their political differences. As recent research on Reclus's New Universal Geography has shown, this was part of a wider anarchist geographers' strategy to engage with mainstream liberal publishers, who were prepared to overlook political unorthodoxy provided that the editorial product was economically profitable. For instance, Kropotkin himself worked for Reclus and was paid directly by Hachette while he was in jail. ${ }^{51}$ For the anarchists, this arrangement was advantageous not only on practical grounds, but because it permitted the dissemination of their scientific work, a key part of their political agendas. The arrangement concluded when pressing political needs called Kropotkin back to everyday struggles in which geographical studies offered limited potential for the pursuit of political ends. Though sympathising with Kropotkin's ideas, Keltie never renounced his moderate beliefs, his Anglocentrism and his common-sense sagacity, urging Kropotkin to avoid 'politicisation' of his scientific work. Nonetheless, Kropotkin always considered his commitment to geography and anarchy as not being mutually exclusive.

From December 1882 to January 1886 Kropotkin was detained in France on the basis of allegations of his involvement in organising riots in Lyon. Despite this, Keltie continued to give him work during this entire period. The letters Keltie and Kropotkin exchanged are also replete with moving declarations of friendship and of Keltie's solidarity with his friend, albeit expressed from a British standpoint, and with an eye to the censors: 'I suppose one must not speak all he thinks in a letter of such an address as yours ... Mrs Keltie and Lizzie are both grieved at the fate of their friend, I think the French government was stupid to make such a blunder. ... Let me say that here in England you have many friends who are grieved for what has happened' ${ }^{52}$ Kropotkin's answers were

\footnotetext{
${ }^{50}$ GARF, 1129, 2, 1309, Keltie to Kropotkin, 5 September 1899. It was Keltie, the appointed sub-editor for the section on geography and statistics of the tenth edition of the Encyclopaedia Britannica, who asked Kropotkin to update the articles on Russia for this publication. For this work, the anarchist prince was paid at the rate of $£ 4$ per page.

${ }^{51}$ Ferretti, The correspondence between Élisée Reclus and Pëtr Kropotkin.

${ }^{52}$ GARF, 1129, 2, 1308, Keltie to Kropotkin, 6 January 1883.

Federico Ferretti, "Publishing anarchist geographies: Pyotr Kropotkin and British print cultures (1877-1917)", Journal of Historical Geography vol. 57, 2017 p. 17-27 doi 10.1016/j.jhg.2017.04.006
} 
always reassuring. In 1883 he noted that 'The chief question for me, at present, is to know if I shall be allowed, at least during a part of the day, to pursue my scientific work. If so, I shall not neglect to supply Nature with useful information' ${ }^{53}$ In the end, Kropotkin managed to provide copy not just for Nature, but, ironically, since he was a detained anarchist, for the Statesman's Year Book, of which Keltie had become editor. ${ }^{54}$ Meanwhile, Keltie was also appointed Inspector of Geographical Education and librarian at the Royal Geographical Society which meant editing the Proceedings of the Society. ${ }^{55}$ Needless to say, this continued to produce more requests for Kropotkin's work at the rate of around $£ 5$ a commission.

It was from his prison cell that Kropotkin wrote his famous paper 'What geography ought to be' in answer to the Report on Geographical Education which Keltie had written and sent to him. ${ }^{56}$ In a letter addressed to Kropotkin's wife and collaborator, Sofia Grigorievna Ananieva-Rabinovich (1856-1938), Keltie noted that Kropotkin's article 'has attracted much attention especially at present when the subject of geographical education is exciting much interest in England' ${ }^{57}$ Though there are no direct discussions on their respective positions between the two men in the surviving correspondence, Kropotkin's paper looks like an endorsement and a complement to Keltie's report. Keltie pronounced his dissatisfaction with geographical teaching in British schools and was especially critical of existing textbooks and rote-learning methods. Kropotkin shared this criticism, arguing for the necessity of enhancing pupils' activism by stimulating their imagination and interest. Kropotkin was also of the view that the scientific periodical press could play a role in the reform of geographical teaching since 'Works both of travel and of general geographical description are becoming again the most popular kind of reading, ${ }^{58}$

Kropotkin was soon back in London, fleeing there on his release in January 1886 to avoid being expelled from France. In the years that followed, Keltie became secretary of the Royal

\footnotetext{
${ }^{53}$ RGS-IBG, Manuscripts CB7, Kropotkin to Keltie, 22 January 1883.

${ }^{54}$ GARF, 1129, 2, 1308, Keltie to Kropotkin, 14 December 1884.

${ }^{55}$ GARF, 1129, 2, 1308, Keltie to Kropotkin, 22 March 1885.

${ }^{56}$ Kropotkin, What geography ought to be; J. Keltie, Geographical Education: Report to the Council of the Royal Geographical Society, London, 1886; GARF, 1129, 2, 1308, Keltie to Kropotkin, 16 August 1885.

${ }^{57}$ GARF, 1129, 2, 1308, Keltie to Sophie Kropotkin, 1 January 1886.

${ }^{58}$ Kropotkin, What geography ought to be, 940 .
}

Federico Ferretti, "Publishing anarchist geographies: Pyotr Kropotkin and British print cultures (1877-1917)", Journal of Historical Geography vol. 57, 2017 p. 17-27 doi 10.1016/j.jhg.2017.04.006 
Geographical Society and editor of the Geographical Journal. According to another RGS fellow acquainted with Reclus and Kropotkin, Hugh Mill (1861-1950), Keltie had to win a 'battle' for popularising geography in which he was supported by the more progressive members of the Council' ${ }^{59} \mathrm{He}$ was also one of the first advocates of women's participation in the RGS, a cause which encountered ferocious resistance from the most conservative members between 1892 and 1914. ${ }^{60}$ During this time Kropotkin was constantly solicited as a reviewer, a translator and a scientific advisor, and from 1895, at Keltie's request, he published a series of papers in The Geographical Journal based on his former explorations of Siberia. ${ }^{61}$ For Kropotkin, this was an opportunity to popularize his earlier studies on glaciation. ${ }^{62}$ The Russian prince was the first to recognize specific glacial forms in Siberia, Finland and Sweden. Once again, this was not devoid of political significance. Nineteenth-century glaciology was part of the new geology which questioned deluge myths and biblical chronologies with the aim of 'freeing science from Moses' ${ }^{63}$ In 1902, Reclus wrote to Kropotkin congratulating him on the fact that his theories had been finally accepted by the majority of scientists. ${ }^{64}$

Indeed, Keltie acted as a sort of literary agent for Kropotkin in Great Britain, finding work for him with journals such as the Newcastle Chronicle. ${ }^{65}$ In doing this he certainly empathised with some of Kropotkin's political views, but he was also eager to avoid the explicit politicisation of the works he edited. For instance, when he put Kropotkin in touch with William Robertson Smith (18461894), then editor of the Encyclopaedia Britannica, on which mutual friends such as Keane were already involved, Keltie wrote that Robertson Smith was 'a Scotch clergyman ... a professor in the Church there but was recently ejected for heresy', a remark which was likely to stimulate the curiosity of the anarchist geographer. ${ }^{66}$ According to Livingstone, Robertson Smith's works on evolutionism were another case of the adaptation of Darwin's theories to specific philosophical

\footnotetext{
${ }^{59}$ H.R. Mill and D. Freshfield, Obituary: Sir John Keltie, The Geographical Journal 69 (1927) 282.

${ }^{60}$ M. Bell and C. McEwan, The admission of women fellows to the Royal Geographical Society, 1892-1914: the controversy and the outcome, The Geographical Journal 162 (1996) 295-312.

${ }^{61}$ GARF, 1129, 2, 1308, Keltie to Kropotkin, 3 and 24 December $1894 .$.

${ }^{62}$ T.K. Ivanova and V.A. Markin, Pëtr Aleksejevic Kropotkin and his monograph 'Researches on the Glacial Period' (1876), London Geological Society Special Publications 301 (2008) 117-128

${ }^{63}$ James A. Secord, Visions of Science: Books and Readers at the Dawn of the Victorian Age, Oxford, 2014, 156.

${ }^{64}$ GARF, 1129, 2, 2103, Reclus to Kropotkin, 16 December 1902.

${ }^{65}$ GARF, 1129, 2, 1308, Keltie to Kropotkin, 31 October 1881.

${ }^{66}$ GARF, 1129, 2, 1308, Keltie to Kropotkin, 15 September and 31 October 1881.
}

Federico Ferretti, "Publishing anarchist geographies: Pyotr Kropotkin and British print cultures (1877-1917)", Journal of Historical Geography vol. 57, 2017 p. 17-27 doi 10.1016/j.jhg.2017.04.006 
and political stances. In this case it was the attempt to find 'revelation in Anthropology'; that is, conciliating evolutionism and Christianity. ${ }^{67}$ Between 1883 and 1888 Kropotkin wrote twentyeight articles for the ninth edition of the Encyclopaedia Britannica. ${ }^{6}$ Unfortunately, the surviving letters Robertson Smith sent to him did not directly address evolution, but they do show an unexpected relationship between an anarchist and a clergyman. Indeed, Robertson Smith introduced Kropotkin to James Geikie (1839-1915), considered at that time, together with his brother Archibald (1835-1924), as one of the champions of free thought and a supporter of science against religion, a position that the anarchist prince clearly endorsed. ${ }^{69}$ Yet the more significant advice that Robertson Smith gave to Kropotkin when they met in Cambridge was to avoid 'political and social lectures', even though he knew that this went against the Russian's activist inclinations. ${ }^{70}$ This matched Keltie's views. A few years later Kropotkin expressed interest in lecturing for an extension scheme at Oxford, and Keltie responded that 'I have reasons to think that if you care about your ... programme you could probably be accepted. But ... you must cut all socialistic lectures'. ${ }^{71}$

The final part of his correspondence with Keltie concerns the 1917 revolution and Kropotkin's subsequent departure for Russia. Keltie was very interested in the 'February Revolution' and in Kropotkin's opinion of it: 'I do not know what your personal views are, if you would please to see the Anarchists or other extremists having the full control or whether [you think that it] is safer that the Liberals ... settle the new regime on a safe and strong basis'. ${ }^{72}$ Keltie had two main concerns. The first was his hope that Russia would continue 'to help the allies to defeat Germany'. ${ }^{73}$ The second was his concern for the health of the seventy-four-year-old Kropotkin if he returned to Russia. ${ }^{74}$ When the Prince confirmed that he was leaving, Keltie urged him to seek medical advice,

${ }^{67}$ D.N. Livingstone, Finding revelation in anthropology: Alexander Winchell, William Robertson Smith and the heretical imperative, British Journal for the History of Science 48 (2015) 435-454.

${ }^{68}$ H. Hug, Peter Kropotkin, Bibliographie, Berlin, 1994, 105-115.

${ }^{69}$ GARF, 1129, 2, 2148, Robertson Smith to Kropotkin, January 29 [1889].

${ }^{70}$ GARF, 1129, 2, 2148, Robertson Smith to Kropotkin, 16 January [1889]. Kropotkin had expressed interest in lecturing in Cambridge, but apparently did not pursue it after this discussion with Robertson Smith.

${ }^{71}$ GARF, 1129, 2, 1308, Keltie to Kropotkin, 12 January 1894. In the end Kropotkin never lectured in Oxford or Cambridge.

${ }^{72}$ GARF, 1129, 2, 1309, Keltie to Kropotkin, 22 March 1917.

${ }^{73}$ GARF, 1129, 2, 1309, Keltie to Kropotkin, 26 March 1917.

${ }^{74}$ GARF, 1129, 2, 1309, Keltie to Kropotkin, 4 April 1917.

Federico Ferretti, "Publishing anarchist geographies: Pyotr Kropotkin and British print cultures (1877-1917)", Journal of Historical Geography vol. 57, 2017 p. 17-27 doi

10.1016/j.jhg.2017.04.006 
arguing that Kropotkin could give great service to Russia, but only if he arrived there in as fit a condition as possible' ${ }^{75}$ For his part, Kropotkin could only concede that: 'Of course I shall not leave England without trying to see my old friends' ${ }^{76}$

Up to this point the political differences between Kropotkin and Keltie had remained mostly implicit, though they certainly existed. For instance, it is possible to argue that the interest of British editors in exploration in Siberia and Central Asia, on which Kropotkin wrote extensively for The Geographical Journal, was related to the geopolitical rivalry between the Russian and British Empires, a subject addressed by another geographer acquainted with Kropotkin, Halford Mackinder. ${ }^{77}$ It was also part of a broader imperial print culture. As Felix Driver notes, Keltie was concerned with filling in the blanks on the map, and praised Henry Morton Stanley (1841-1904) for his explorations in Africa. ${ }^{78}$ In contrast, Stanley was harshly criticized by the anarchist geographers who considered him an advocate of a 'murdering civilisation' that massacred and subjugated non-European peoples in the name of a pretended progress. ${ }^{79}$

In his obituary of Kropotkin in 1921, Keltie again separated Kropotkin's politics and his contribution to geography:

'He had left England, which had been his home for many years, for Russia in 1917, after the revolution had broken out, no doubt with the hope that his "anarchist" aspirations would be realized on a large scale. It need hardly be said that he was grievously disappointed. But this is not the place to deal in detail with Kropotkin's political views, except to express regret that his absorption in these seriously diminished the services which otherwise he might have rendered to Geography'. ${ }^{80}$

\footnotetext{
${ }^{75}$ GARF, 1129, 2, 1309, Keltie to Kropotkin, 11 April 1917.

${ }^{76}$ RGS-IBG Manuscripts CB7, Kropotkin to Keltie, 17 April 1917.

${ }^{77}$ Kearns, Geopolitics and Empire, 263-296.

${ }^{78}$ F. Driver, Geography Militant, Cultures of Exploration and Empire, Oxford, 2001, 120.

${ }^{79}$ Ferretti, The murderous civilization.

${ }^{80}$ J. Keltie, Obituary: Prince Kropotkin, The Geographical Journal 57 (1921) 316-317.
}

Federico Ferretti, "Publishing anarchist geographies: Pyotr Kropotkin and British print cultures (1877-1917)", Journal of Historical Geography vol. 57, 2017 p. 17-27 doi 10.1016/j.jhg.2017.04.006 
In contrast, for Kropotkin, geography was a part of an overall idea of 'science' and that was inseparable from politics. In 'What geography ought to be' he argued that 'remaining a natural science, [geography] would assume, together with history ... the immense task of caring about the humanitarian side of our education'. ${ }^{81}$ Moreover, one of Kropotkin's most important books addressing the relations between science and anarchism, Mutual Aid, was strongly grounded in the cultures of exploration to which Kropotkin contributed in his early years in Siberia. ${ }^{82}$ For Kropotkin, geography and politics were inseparable.

Thus, to understand the political relevance, for Kropotkin, of collaborating with scholars such as Keltie on geographical works, it is necessary to consider his biography. When Kropotkin returned to England in 1886 he was forty-four years old with over twenty-five years of exploration, incarceration and political exile behind him, and his life became suddenly less adventurous. Accepting that 'knowledge usually does not move around the world as an immaterial entity', it is possible to appreciate how these material conditions allow an explanation of Kropotkin's strategies. ${ }^{83}$ Kropotkin's political commitment through science was consistent with his new worklife situation, for at least two reasons. First, he considered anarchism a science. Second, he was then enrolled in the transnational anarchist networks in London and also continued to make a significant contribution to the continental anarchist press. ${ }^{84}$ His return to Russia showed that he never renounced active commitment, but that, while in London, he just expressed it through his work for British periodicals' reading publics. His correspondence with Keltie shows the 'new' Kropotkin's position as an established intellectual, using his assets to put his ideas before the public. The next section shows how this was done by explaining Kropotkin's parallel collaboration with the principal architect of his popularity with British readers, James Knowles.

\section{‘ANOTHER TURN AT THE BISHOPS?' KROPOTKIN AND KNOWLES}

${ }^{81}$ Kropotkin, What geography ought to be, 946.

${ }^{82}$ Bassin, Imperial Visions; L. Dugatkin, The Prince of Evolution: Peter Kropotkin's Adventures in Science and Politics, Charleston, 2011.

${ }^{83}$ Livingstone, Science, text and space, 391.

${ }^{84}$ Kinna, Kropotkin, 27-28; Di Paola, The Knights Errant; Bantman, The French Anarchists; I. McKay, Kropotkin, Woodcock and Les Temps Nouveaux, Anarchist Studies 23 (2015) 62-85.

Federico Ferretti, "Publishing anarchist geographies: Pyotr Kropotkin and British print cultures (1877-1917)", Journal of Historical Geography vol. 57, 2017 p. 17-27 doi 
Knowles - the protagonist of Victorian cultural scenes as the editor for the Contemporary Review and then for The Nineteenth Century - was undoubtedly the most important of Kropotkin's British publishers. It has been observed that 'the Contemporary, at least while James Knowles remained editor, featured some of the most ferocious arguments by Huxley, Tyndall, William Kingdon Clifford, and other scientific professionalisers in favour of the authority of trained scientific experts on social, intellectual and cultural questions that had traditionally been the province of clergymen'. ${ }^{85}$ After his rupture with the publishers of the Contemporary Review, whom he accused of limiting his freedom as an editor, Knowles wanted to found 'a new liberal monthly under his sole proprietorship'. ${ }^{86}$ This happened in 1877 with the foundation of The Nineteenth Century, which has been seen as exercising 'a very striking influence on both periodical literature and on liberal thought in general' ${ }^{87}$ According to Knowles's biographer, Priscilla Metcalf, he was interested in Kropotkin's writings because intellectual anarchism 'seemed an acceptable, even glamorous eccentricity, in London' ${ }^{88}$ Against this, I argue that the correspondence with Knowles shows that intellectual anarchism should be taken seriously, as Kropotkin clearly followed and radicalized Knowles's commitment to 'free' and independent science.

According to Metcalf, Kropotkin and Knowles first met in 1886. Their letters show that they were already corresponding by 1882 , prior to Kropotkin's imprisonment in France, and that they remained in touch until 1906. A friend of Lord Gladstone, Knowles was far from revolutionary concerns, but he saw the value of socialism for reflecting on the failure of classical economics. ${ }^{89}$ The first surviving letter from Knowles to Kropotkin, dated November 1882, was tragically prophetic because its subject was Kropotkin's article on Russian prisons, published in The Nineteenth Century a few weeks before Kropotkin's arrest in France. Knowles was concerned with the situation of human rights in Russia, and considered Kropotkin's paper as 'terrible in its statements of a condition of things which European public opinion will alone, I suppose, be likely

\footnotetext{
${ }^{85}$ Dawson, Noakes and Topham, Introduction, 21.

${ }^{86}$ Small, Science, liberalism and the ethics of belief, 248

${ }^{87}$ G. Gooday, Profit and prophecy: electricity in the late-Victorian periodical, in Cantor, Dawson, Gooday, Noakes, Shuttleworth and Topham, Science in the Nineteenth-Century Periodical, 243.

${ }^{88}$ P. Metcalf, James Knowles: Victorian Editor and Architect, Oxford, 1980, 325.

${ }^{89}$ Metcalf, James Knowles, 324 and 327.

Federico Ferretti, "Publishing anarchist geographies: Pyotr Kropotkin and British print cultures (1877-1917)”, Journal of Historical Geography vol. 57, 2017 p. 17-27 doi 10.1016/j.jhg.2017.04.006
} 
to change' ${ }^{90}$ In an 1884 letter, Knowles raged, in a rather astonishing way if we consider that Kropotkin was then a political prisoner in France, about the 'Russian treatment of political prisoners' ${ }^{91}$ For Knowles, Kropotkin's imprisonment was not the occasion of warm declarations of solidarity, as it was for Keltie, but it did not interrupt their collaboration either. Thus, another liberal British editor shared Kropotkin's critique of Russian autocracy and these shared convictions formed the basis for a collaboration which profited both sides economically and politically. In 1883 Knowles asked Kropotkin to write an article on Siberia, adding that he had sent 'to Madame Sophie Kropotkine a cheque for $£ 20$ ' at her Geneva address. ${ }^{92}$ This shows an important characteristic of the collaboration between Kropotkin and Knowles. If Keltie's payments, often delayed, were generally around four or five pounds, the articles Kropotkin wrote for Knowles's journals were paid in advance at rates from twenty to fifty pounds each. This made The Nineteenth Century one of Kropotkin's most important employers, having commissioned from him more than thirty long papers starting in 1882 .

However, Kropotkin did not just accept editorial commissions. Knowles's letters show that in almost all cases the proposals came from the Russian geographer. On being sent an article called 'Petty trades and Grand Factories', Knowles declared that he was 'delighted to receive [it]', as well as a subsequent 'manuscript on the Integration of Labour' ${ }^{93}$ These pieces of work later became a part of Kropotkin's book Fields, Factories and Workshops. ${ }^{94}$ According to Adams, this work, 'adapted from lengthy articles contributed to The Nineteenth Century, examined the possibility of regional self-sufficiency in Britain, secured through an integration of agriculture and industry, and overcoming the division between brain work and manual work'. It became a key element in anarchist thought. ${ }^{95}$ In comparison to Keltie's publications, The Nineteenth Century's format allowed a more explicit discussion of social and political topics, which explains Kropotkin's commitment to proposing new papers for Knowles. Its format also engaged a new public. The twenty-six centimetre pages of The Nineteenth Century, without columns and with a minimum

${ }^{90}$ GARF, 1129, 2, 1895, Knowles to Kropotkin, 8 November 1882.

${ }^{91}$ GARF, 1129, 2, 1895, Knowles to Kropotkin, 15 November 1884.

${ }^{92}$ GARF, 1129, 2, 1895, Knowles to Kropotkin, 9 January 1883.

${ }^{93}$ GARF, 1129, 2, 1895, Knowles to Kropotkin, 14 April 1885 and 11 February 1888.

${ }^{94}$ P. Kropotkin, Fields, Factories and Workshops, London, 1898.

${ }^{95}$ Adams, Kropotkin, 17.

Federico Ferretti, "Publishing anarchist geographies: Pyotr Kropotkin and British print cultures (1877-1917)", Journal of Historical Geography vol. 57, 2017 p. 17-27 doi 10.1016/j.jhg.2017.04.006 
apparatus of bibliography and notes, could be considered as 'attractive and easy on the eye' and simple to read for a wide audience. ${ }^{96}$ Moreover, the possibility of publishing a long work in monthly chapters had the double advantage of allowing a rapid interaction with the public involved in scientific debates and the opportunity of reprinting them as popular books to enhance and diversify their readership. Kropotkin's geographical work for this periodical can be seen as part of what Mayhew argues was a 'profound change in the reading experience of geography' with a shift toward agreeable 'literary form' to engage the reader. ${ }^{97}$

As an editor, Knowles's concerns seemed more commercial than political. A recurrent point of discussion with Kropotkin was Knowles's claim to exclusive rights over commercial exploitation of the texts. There is evidence here of the first clash between the interests of the anarchist propagandist, targeting the wide circulation of his writings, and the editor interested in their sales. Back in London after his liberation, Kropotkin received from Knowles a number of proposals for publishing his recollections. The editor wanted the former prisoner to 'reserve [them] jealously for the Nineteenth Century and decline [any offer from] newspapers'. ${ }^{98}$ These recollections became the book In French and Russian Prisons (1889) which Knowles requested that Kropotkin specified was published 'with the Nineteenth Century's permission'. ${ }^{99}$ In these negotiations the author had his own power and agency. Kropotkin exploited Knowles's editorial strategy of publishing a series of articles in consecutive issues to give himself enough space to develop his arguments. He then used these as the basis for a book. For instance, Knowles's 1886 acknowledgement of the 'promise to write for me three articles of about 15 pages each ... on the "scientific basis of anarchy", resulted in a couple of papers published in 1887, 'The scientific basis of anarchy' and 'The coming anarchy', which became the key book Modern Science and Anarchism. ${ }^{100}$ If the strategy of serial publication was economically profitable for Knowles, Kropotkin strove systematically for the republication of these series in book form for propaganda purposes. In this way, Kropotkin managed to get paid as a full-time anarchist propagandist. In this context, it is worth noting that

\footnotetext{
${ }^{96}$ Mayhew, Materialistic hermeneutics, 485.

${ }^{97}$ Mayhew, Materialistic hermeneutics, 483, 485.

${ }^{98}$ GARF, 1129, 2, 1895, Knowles to Kropotkin, 19 January 1886.

${ }^{99}$ P. Kropotkin, In Russian and French prisons, London, 1887; GARF, 1129, 2, 1895, Knowles to Kropotkin, 4 December 1886.

${ }^{100}$ GARF, 1129, 2, 1895, Knowles to Kropotkin, 9 March 1886; Kropotkin, Modern Science; Kinna, Kropotkin. Federico Ferretti, "Publishing anarchist geographies: Pyotr Kropotkin and British print cultures (1877-1917)”, Journal of Historical Geography vol. 57, 2017 p. 17-27 doi 10.1016/j.jhg.2017.04.006
} 
The Nineteenth Century assured him a huge readership, being the most important British monthly by number of printed copies, around twenty thousand for each number in the $1880 \mathrm{~s} .{ }^{101}$

The relationship between politics and commerce was a complex one. In a striking 1881 note, Keltie had expressed perplexity about a book that Kropotkin proposed in which we find an early definition of the idea of mutual aid. One of the publishers consulted by Keltie was 'very doubtful about your proposed book on the Law of Mutual Help and can hardly give a definitive answer before seeing your article'. ${ }^{102}$ Thus, Keltie and his contacts had been unable to grasp the editorial potential of the idea of mutual help, while Knowles accepted it enthusiastically, writing in 1889: 'Let me see the other articles on "Mutual animal help". The subject is exceptionally interesting and the treatment at your hands will be equally so'. ${ }^{103}$ In addition, in 1886 the Contemporary Review had published Metchnikoff's paper on 'Revolution and Evolution', anticipating some of Kropotkin's theories that the two Russians had collectively discussed with Reclus. Kropotkin also put Metchnikoff in contact with Knowles, who received his 'manuscript on the Jews in Russia', but did not publish it. ${ }^{104}$ Kropotkin's papers on mutual aid paralleled the writings by Knowles's friend Thomas Huxley (1825-1895) and challenged his idea of competition by considering cooperation as a part of evolutionary processes. The 'Mutual Aid' series would be published in The Nineteenth Century until 1919 with sequences of two or three papers in consecutive issues because Knowles thought it was 'such a pity to divide [a paper] from its sequel'. ${ }^{105}$ Their republication as books, starting with the 1902 British edition of Mutual Aid, was the object of negotiations where Knowles would, in principle, 'make no objection' but did try to maintain a certain control over the texts and personally negotiate with the publishers, warning Kropotkin that 'the copyright of these articles legally belongs to me for 28 years' ${ }^{106}$ The conflict between the commercial exploitation of these texts and their political use emerges clearly in a letter in which Knowles forbade the republication of some of Kropotkin's papers in the Belgian socialist journal Humanité Nouvelle. ${ }^{107}$

\footnotetext{
${ }^{101}$ Metcalf, James Knowles, 285.

102 GARF, 1129, 2, 1308, Keltie to Kropotkin, 11 March 1881.

${ }^{103}$ GARF, 1129, 2, 1895, Knowles to Kropotkin, 19 January 1889.

${ }^{104}$ GARF, 1129, 2, 1895, Knowles to Kropotkin, 17 October 1883.

105 GARF, 1129, 2, 1895, Knowles to Kropotkin, 30 November 1895.

${ }^{106}$ GARF, 1129, 2, 1895, Knowles to Kropotkin, 20 March and 9 July 1896.

${ }^{107}$ GARF, 1129, 2, 1895, Knowles to L'Humanité Nouvelle, 21 August 1897.
}

Federico Ferretti, "Publishing anarchist geographies: Pyotr Kropotkin and British print cultures (1877-1917)”, Journal of Historical Geography vol. 57, 2017 p. 17-27 doi 10.1016/j.jhg.2017.04.006 
In 1891 Knowles offered $£ 50$ to Kropotkin 'if you would write [your] next [paper] for me on Recent Science', proposing a delay to the ongoing article on mutual aid, which he considered less urgent. ${ }^{108}$ For the next ten years, Knowles constantly harassed Kropotkin for this series, while the author seemed reluctant to write it and admitted that he was 'writing for a salary on scientific matters, which are frightfully boring to me and are absorbing my time and annoying me'. ${ }^{109}$ Regardless, Knowles's letters confirm that Kropotkin eventually fully satisfied the editor's requests. ${ }^{110}$ The delay was not, however, because Kropotkin saw a division between science and politics. According to Graham Purchase, Kropotkin's columns on Recent Science were 'remarkable for their detailed research', revealing the extent of Kropotkin's reading on the most up-to-date scientific debates. ${ }^{111}$ It is clear, therefore, that anarchist geographers such as Kropotkin had taken sides in the political battles over science between the liberal and conservative parts of British society. ${ }^{112}$ Knowles, who published papers by both Huxley and by one of the clerical exponents, the Duke of Argyll, George Douglas Campbell (1823-1900), promoted evolutionism, as his letters to Huxley and Kropotkin show. For instance, he asked Huxley 'When are you going to take your next shy at the Duke?' and again, 'How about another turn at the bishops?' ${ }^{113}$ When Kropotkin complained about Campbell, Knowles replied that, 'As regards the Duke of Argyll, I quite share your objection to polemics on such subjects. They always offend more directly with science than with any other branch of human enquiry'. ${ }^{114}$

In 1889 another series of articles was launched, one that addressed the 1789 French Revolution on its anniversary. In this case the proposal came from Knowles, leading to another classic work by Kropotkin, The Great French Revolution - 1789-1793. ${ }^{115}$ Knowles wrote to Kropotkin that he was

\footnotetext{
${ }^{108}$ GARF, 1129, 2, 1895, Knowles to Kropotkin, 16 April 1891.

${ }^{109}$ Metcalf, James Knowles, 324.

${ }^{110}$ GARF, 1129, 2, 1895, Knowles to Kropotkin, 18 May 1892.

${ }^{111}$ G. Purchase, Peter Kropotkin: Ecologist, Philosopher and Revolutionary, Sydney, 2003, 34.

112 J. Secord, Victorian Sensation: the Extraordinary Publication, Reception, and Secret Authorship of Vestiges of the Natural History of Creation, Chicago, 2000, 261-296; G.W. Stocking, After Tylor: British Social Anthropology, London, 1995, 3-83.

${ }^{113}$ Metcalf, James Knowles, 323.

${ }^{114}$ GARF, 1129, 2, 1895, Knowles to Kropotkin, 26 March 1894.

115 P. Kropotkin, The Great French Revolution - 1789-1793, London, 1909.

Federico Ferretti, "Publishing anarchist geographies: Pyotr Kropotkin and British print cultures (1877-1917)”, Journal of Historical Geography vol. 57, 2017 p. 17-27 doi 10.1016/j.jhg.2017.04.006
} 
most interested 'in this moment especially anything you might say about it' ${ }^{116}$ For Kropotkin, the commission allowed him to develop his ideas about the lineages of anarchism. As he argued, the revolutionary years before the Jacobin Terror were one of the key historical experiences of libertarian popular mobilisation as opposed to the authoritarianism of subsequent political leaders from Robespierre to Bonaparte. This experience, Kropotkin argued, inaugurated two kinds of socialism: the first, authoritarian, went from Jacobinism to Marxism; the second, libertarian, characterised the anarchists. Kropotkin corresponded extensively with Guillaume, the other anarchist scholar of the French Revolution, and this interpretation became canonical in the French anarchist movement as well as being made available for a broader British reading public. ${ }^{117}$

The relationship between Knowles and Kropotkin came to an end when a rift developed over the 1905 Russian revolution. Their different views first emerged in 1894 when Knowles submitted his objections to Kropotkin about a paper on the 'Condition of Russia'. Significantly, the point of contention was The Nineteenth Century's availability to unconditionally bring Kropotkin's voice to the public. Knowles, unhappy with the radical criticism of the new czar that Kropotkin was putting forward, used a series of sophistries to convince his correspondent to revise his paper or to delay its publication. 'Your article', he wrote, 'is a little out of harmony with the present ... state of public sentiment'. The editor claimed a better knowledge of the Anglophone public and argued that his amendments 'would put the English reader at once into a sympathetic mood to read the ... tale which has to be told'. ${ }^{118}$ This position implied something similar to a soft censorship, which disturbed Kropotkin. Even reading only Knowles's letters it is clear that the negotiation was long and difficult. They finally agreed that Kropotkin could freely criticise the new czar, but that Knowles, once the author was paid, had the right to delay its publication until 'the right moment' to not interfere with British diplomacy. ${ }^{119}$

\footnotetext{
${ }^{116}$ GARF, 1129, 2, 1895, Knowles to Kropotkin, 18 May 1889.

117 Bibliothèque de Genève, Département des Manuscrits, Microfilm 853, lettres de J. Guillaume à P. Kropotkin; G. Manfredonia, Les anarchistes et la Révolution Française, Paris, 1990.

118 GARF, 1129, 2, 1895, Knowles to Kropotkin, 31 December 1894.

119 GARF, 1129, 2, 1895, Knowles to Kropotkin, 5 January 1895.
}

Federico Ferretti, "Publishing anarchist geographies: Pyotr Kropotkin and British print cultures (1877-1917)”, Journal of Historical Geography vol. 57, 2017 p. 17-27 doi 10.1016/j.jhg.2017.04.006 
After 1900 Kropotkin's contributions became more sporadic, leading Knowles to complain 'Alas, you get rarer and rarer'. ${ }^{120}$ While he celebrated the 'great news' that Kropotkin's 'articles may now be circulated in Russia', he restricted their publication in Britain. ${ }^{121}$ A 1906 Kropotkin paper denouncing the 'White terror' that followed the 1905 revolution was judged by Knowles as 'terrible and awful. Too terrible for me to publish it as it stands'. ${ }^{122}$ Kropotkin's answers, surviving in Knowles's archives in Westminster, show that the Russian prince, although 'awfully disappointed about the article', was disposed not only to renounce his wage but also to collect money for the hypothetical expenses that Knowles feared in case of legal action by the Russian embassy. ${ }^{123}$ Kropotkin's urgent political problem was attracting the interest of Western public opinion to the repression in Russia and he considered the editor's unwillingness to publish as morally unacceptable behaviour. ${ }^{124}$ An intervention by Kropotkin's wife, who wrote to Knowles 'against [her] husband approval', to implore him to help the cause of Russian revolutionaries, was useless. ${ }^{125}$ In his last letter, Knowles wrote to the prince that he hoped they could maintain 'personal relations'. ${ }^{126}$ However, no more contacts are documented between the two men. In 1908, after Knowles's death, Kropotkin wrote to his widow saying that Knowles had been 'one of [his] best personal friends in England' and restarted a collaboration with the editor's son-in-law and successor at The Nineteenth Century, William Skilbeck, with whom he published the last series on mutual aid. ${ }^{127}$

In contrast to his relationship with Keltie, it was often Kropotkin who solicited Knowles, for both economic and political reasons. The fact that the series edited by Knowles became anarchist classics once published in book form shows the seamless connection between Kropotkin's anarchism and his commitment to scientific publishing in Britain. This took advantage of the nascent discipline of geography, which, according to Withers, was able to fill British public halls

\footnotetext{
${ }^{120}$ GARF, 1129, 2, 1895, Knowles to Kropotkin, 16 July 1901.

${ }^{121}$ GARF, 1129, 2, 1895, Knowles to Kropotkin, 13 November 1905.

${ }^{122}$ GARF, 1129, 2, 1895, Knowles to Kropotkin, 25 March 1906.

${ }^{123}$ City of Westminster Archives Centre [CWAC], 716/84, Kropotkin to Knowles, 27 March 1906.

${ }^{124}$ CWAC, 716/84, Kropotkin to Knowles, 30 March 1906.

${ }^{125}$ CWAC, 716/84, Kropotkin to Knowles, 4 April 1906.

${ }^{126}$ GARF, 1129, 2, 1895, Knowles to Kropotkin, 2 April 1906.

${ }^{127}$ CWAC, 716/84, Kropotkin to Lady Knowles, 18 February 1908 and Kropotkin to Skilbeck, 10 July 1908. Federico Ferretti, "Publishing anarchist geographies: Pyotr Kropotkin and British print cultures (1877-1917)", Journal of Historical Geography vol. 57, 2017 p. 17-27 doi 10.1016/j.jhg.2017.04.006
} 
during the Victorian period. ${ }^{128}$ However, the competing aims, commercial and political, of Knowles and Kropotkin also evoke another issue of geographical publishing in the industrial age. This is what Keighren, Withers and Bell define as the commodification of knowledge and the subsequent alienation of authors within their activity, which became 'an industrial process' ${ }^{129}$ Thus, it is possible to make sense of Kropotkin's attempts to keep full control of his texts (in paper or book form) in order to take advantage of them not only economically, but also politically, in the context of 'the ability of authors and publishers to control and manage the use of the words that are printed under their names once there are replicated'. ${ }^{130}$

\section{CONCLUSION}

This paper has shown how biographical and editorial opportunities and constraints played a key role in shaping Kropotkin's anarchist geographies, which need to be understood in both their material and social contexts. The analysis of archives and primary sources, especially correspondence, proves to be a fundamental tool for understanding the materiality of militant and scholarly work. In addition, the concept of sociability allows a better understanding of contexts, places and transfers in the production of knowledge because it helps in analysing transnational and informal networks based on friendship, mutual trust and practical bargains, as in the case of Kropotkin and Keltie. For Kropotkin, a scholar who did not hold any academic or institutional appointment, analysing the networks of scientific sociability he built around publishing projects and learned societies is especially helpful for understanding the intellectual strategies he deployed and their implicit and explicit links with his political commitments.

Likewise, this approach enables a more comprehensive understanding of the elements of continuity and coherence between geography and anarchism, and between the two main parts of Kropotkin's life, before and after 1886. The fact that, unlike Keltie, Kropotkin did not conceive of any formal divide between science and politics helps explain the bargains that he made with his British publishers. He deemed anarchism a science, and his first articulations of the ties between science

\footnotetext{
${ }^{128}$ Withers, Geography and Science in Britain, 1831-1939: A Study of the British Association for the Advancement of Science, Manchester, 2010.

${ }^{129}$ Keighren, Withers and Bell, Travels Into Print, 176.

${ }^{130} \mathrm{G}$. Dawson, The Review of Reviews and the new journalism in late-Victorian Britain, in Cantor, Dawson, Gooday, Noakes, Shuttleworth and Topham, Science in the Nineteenth-Century Periodical, 177.

Federico Ferretti, "Publishing anarchist geographies: Pyotr Kropotkin and British print cultures (1877-1917)”, Journal of Historical Geography vol. 57, 2017 p. 17-27 doi 10.1016/j.jhg.2017.04.006
} 
and militancy were developed through ideas of social emancipation via knowledge and popular education. For his editors, their collaboration was justified on commercial grounds, friendship, liberal mentalities and some shared views. Ironically, Keltie and Knowles both supported radical social reforms, but not in England. On this common terrain Kropotkin built a convincing strategy to present his ideas to British publics by establishing the editorial compromises outlined above, a strategy which paralleled Reclus's work with the publishers Hetzel and Hachette in France. However, the ambiguities and limits of this personal strategy were exposed by the revolutions of 1905 and 1917 when Kropotkin's claims for more vocal support were not responded to by his British editors.

The periodical press played a key role in these collaborative bargains and secured a durable public success for Kropotkin's works. The growing popularity of scientific periodicals broadened geography's publics, and facilitated the programme Kropotkin expressed in 'What geography ought to be'. The importance for Kropotkin of keeping authorial control over his texts, securing both their publication and circulation is demonstrated by his reactions when this control was threatened, as the 1906 exchanges with Knowles show. Direct editorial constraints, explicitly motivated by political reasons, became intolerable to the Anarchist Prince. Notwithstanding this, Kropotkin's publishing strategy was generally successful since he was able to publish his views without major constraints for several decades. While contemporary understanding shows the importance of the periodical press in shaping and disseminating scientific ideas, it is also possible to conclude that Kropotkin's commitment to these publishing cultures permits a questioning of the commonly-held view that anarchist geographers were marginalised. ${ }^{131}$ Working with these publishers, anarchists were no less popular, as scientists, than 'mainstream' authors. Given Kropotkin's celebrated standing, and his close association with Keltie and Knowles, he became one of the main protagonists of the alliance between science and the periodical press. Anarchism was thus intrinsic to this alliance in Victorian Britain.

In the context of more general debates on science, religion and politics at that time, Kropotkin's collaboration with Keltie and Knowles was especially important because of their common interest

\footnotetext{
${ }^{131}$ G. Cantor and S. Shuttleworth, Introduction, in G. Cantor and S. Shuttleworth (Eds.), Science Serialized, 13. Federico Ferretti, "Publishing anarchist geographies: Pyotr Kropotkin and British print cultures (1877-1917)”, Journal of Historical Geography vol. 57, 2017 p. 17-27 doi 10.1016/j.jhg.2017.04.006
} 
in rational science and their jointly-held views on the challenges facing the church and other establishment institutions. Keltie was instrumental in Kropotkin's rise as a popular author for the British press, not least due to their common interest in secular and rational science and their hatred for Russian autocracy. Yet, Knowles was more astute than Keltie in understanding the editorial relevance of some Kropotkin's ideas. Whilst Kropotkin's influential work on mutual aid was refused for publication by Keltie in 1881, its full scientific and commercial potential was recognized by Knowles, who published it in a series of papers after 1889, launching the Russian into mainstream Darwinist debates. ${ }^{132}$ As Adams argues, Kropotkin choosing to engage with liberal authors such as Herbert Spencer was 'the product of a calculated attempt to translate anarchism into English' on evolutionist grounds. ${ }^{133}$ By examining Kropotkin's relationship with his British editors this paper has placed Kropotkin's evolutionism within both the context of expanding international anarchist networks and histories of British print cultures and the periodical press. Both were essential in the popularization of Darwinism amongst all social classes and might enable present-day critical, radical and anarchist geographies to find ways of dealing with the present return of Malthusianism, Creationism, environmental determinisms and religious fanaticisms. ${ }^{134}$

\footnotetext{
${ }^{132}$ Livingstone, Science, text and space.

${ }^{133}$ Adams, Kropotkin, 54-55.

${ }^{134}$ G. Dawson, The Cornhill Magazine and shilling monthlies in mid-Victorian Britain, in G. Cantor, G. Dawson, G. Godday, R. Noakes, Shuttleworth and Topham, Science in the Nineteenth-Century Periodical, 123-150.

Federico Ferretti, "Publishing anarchist geographies: Pyotr Kropotkin and British print cultures (1877-1917)”, Journal of Historical Geography vol. 57, 2017 p. 17-27 doi 10.1016/j.jhg.2017.04.006
} 